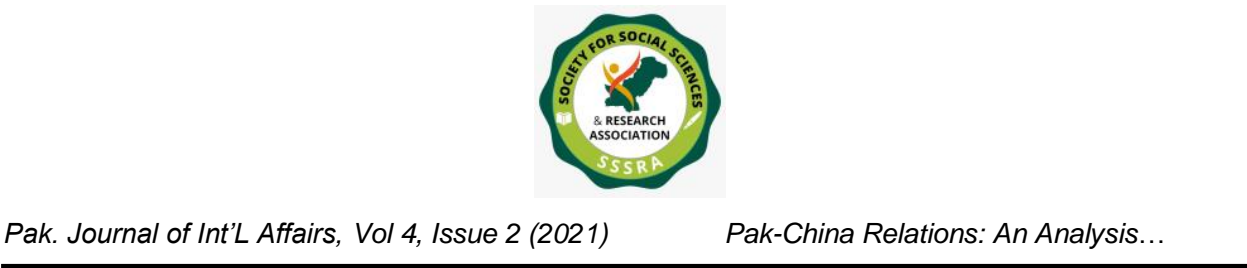

\title{
PAK-CHINA RELATIONS: AN ANALYSIS
}

\author{
Farhana Kosar \\ Research Scholar Ph.D \\ Department of International Relations \\ Federal Urdu University of Arts, Sciences \& Technology \\ Karachi-Pakistan \\ farhanakauser0209@gmail.com
}

\begin{abstract}
It is necessary to explore Pakistan-China relations in terms of their longterm bilateral contacts, including the history and evolution of their longterm bilateral ties, as well as the factors and environment that led to the consolidation of their strategic dependence. The two nations established diplomatic connections to begin their bilateral relations, which have since developed into close allies. Afterwards, they deepened their engagement with one another and strengthened their strategic reliance, which they nicknamed the "Iron Brothers" partnership. Throughout the course of this study, the foundations of comprehensive cooperation in Pakistan-China relations at various phases of their evolution are examined, as well as the imperatives of interdependence between the two countries. Particular attention is paid to the relevance of China in the increasing dynamics of South Asia, including India's ambitions to gain regional dominance and its connections with other nations, notably the United States, and the significance of China in the rising dynamics of South Asia. According to the conclusion of the talk, the imperatives of regional security, notably the growing Indo-US collaboration, have given rise to new dimensions in Pakistan's relationship with China in the years after September 11, 2001.
\end{abstract}

Keywords: Pakistan, China, South Asia, Iron Brothers, Regional Security.

\section{Introduction}

The Pakistan-China collaboration is a success storey with a lot of promise, with a lot of potentials to meet the demands of changing global and regional geostrategic and geoeconomic circumstances. Both countries usually refer to their prospective partnership as "all-weather friendship" and "all-round cooperation," which is an apt description. The 


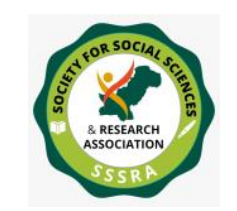

Pak. Journal of Int'L Affairs, Vol 4, Issue 2 (2021)

Pak-China Relations: An Analysis...

growth of Pakistani-Chinese relations has been on a continuous upward trajectory. Pakistan-China relations, which are founded on shared interests, have their own dynamics and are expected to thrive in the future. Both countries are very crucial to one another on a strategic level. Precisely what makes Pakistan and China unique, as well as the outlines of their bilateral relationship, are well-documented and much argued in both countries, as well as abroad at the regional and global levels. That the link has endured through the ups and downs of time for more than six and a half decades and continues to grow stronger is unquestionable and requires little further explanation or justification. (Bhatti, 2008) With no question in my mind, this partnership can serve as a model for relationships between any two states in the modern world. When it comes to bilateral exchanges, political and strategic aspects have always been the focus - and have continued to be so throughout the decades from 1951 to 1990 - but we are now witnessing a shift towards closer and more dynamic economic ties, as well as more robust people-to-people exchanges, in the period following 2000, the first 17 years of the twenty-first century. Currency Swap Agreement, FTA Agreement, framework agreements for economic and energy cooperation, and a variety of programmes for academics, professionals, youth and students and artists to mention a few are some of the most notable advances on this front during this period. Pakistan and China's relationship has been revitalised with the formal launch of the China-Pakistan Economic Corridor in April 2015, which included the official opening of CPEC projects. It goes without saying that both nations stand to gain significantly from this massive endeavour, which is expected to provide significant economic, socioeconomic, political, and strategic rewards, particularly in the long run, as well as political and strategic dividends. The purpose of today's discussion, which is themed "PakistanChina Relations: CPEC and Beyond," is to emphasise that, while the China-Pakistan Economic Corridor (CPEC) has justifiably earned symbolic prominence in bilateral interactions, it represents only one part of those relations. Indeed, bilateral relations extend much beyond the China-Pakistan Economic Corridor (CPEC), as they contain a wide range of other key characteristics, including political and strategic ones, that are expected to have a bigger influence on contemporary regional and international dynamics. Even though the China-Pakistan Economic Corridor (CPEC) has grabbed centre stage in the conversation at practically all levels, ties between China and Pakistan need to be understood in a much larger context. (Afridi \& Khan, 2015)

\section{The Era of the Cold War}

The Sino-Indian War of 1962 provided a chance for closer ties between the two countries because of their shared objectives. They became close friends and partners throughout the following period of their partnership (1963 to 1988) when they solidified their connection. Pakistan and China became strategic allies after realising the necessity of the 


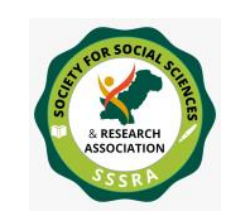

Pak-China Relations: An Analysis...

other in countering the Indian menace. In March 1963, they reached an agreement on the delineation of their shared boundary as a result of this geostrategic context. Both countries benefited from the arrangement. Pakistan and China decided to rewrite the border agreement following the conclusion of the Jammu and Kashmir issue in order to avoid any repercussions from this deal. The deal was not accepted by India. Other key accords, including an aviation service and commerce pact, were also inked by the two nations. In August 1963, Pakistan signed an aviation service deal with Pakistan International Airlines (PIA) that allowed PIA to assist the travel of Chinese officials to Europe and Africa via Karachi in 1964. This arrangement was essential in eliminating China's isolation. Chinese Muslims were also connected to other Muslim countries through this linkage. Agreements signed by the two countries enabled the landing of Pakistani aircraft in Shanghai and Canton. Pakistan reciprocated by allowing Chinese planes to land at Dhaka International Airport. Such a development was not welcomed by the United States of America. (PCI, 2018)

An "unfortunate violation of free world solidarity" led to a delay in a loan of US\$4.3 million to modernise Dhaka's airport, according to the U.S. State Department's statement. Chou Enlai, the Chinese Prime Minister, visited Pakistan in February 1964. In December 1964, Pakistan's President General Ayub Khan travelled to China to meet with Chinese leaders. In the early 1970s, secret encounters between the US and China, particularly those between President Richard Nixon and Secretary of State Henry Kissinger, aided significantly in normalising Sino-US relations. India and the former Soviet Union expressed dissatisfaction with the normalisation of US-China ties. On August 9, 1971, as a result of the US-Pakistan-China strategic triangle, India signed a treaty of peace, friendship, and cooperation with the Soviet Union. Swaran Singh, India's foreign minister, and Andrei Gromyko, the Soviet Union's foreign minister, signed the agreement. According to Article IX, "the high contracting parties shall promptly enter into bilateral negotiations in order to remove such threat and to take necessary and effective steps to safeguard peace and security of their nations," the treaty was deemed a security pact. Military and economic aid from China were essential to Pakistan's defence against India during and during the 1965 and 1971 wars with India. Following India's nuclear test in 1974, Pakistani and Chinese defence cooperation advanced again more. The building of the Karakoram Highway (KKH) began in 1959 and was finished in 1978 with the assistance of China. On June 8, 1978, Chinese Vice Premier Kang Piao and General Zia-ul-Haq inaugurated it in Islamabad. (Curtis, 2009)

A cornerstone for Pakistan-China commerce and people-to-people ties, the KKH serves as a gateway. It is also an excellent tool for promoting tourism between the countries. During an official visit to China in 1980, General Zia-ul-Haq met with Chinese officials. 


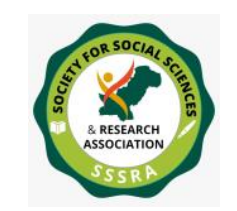

Pak. Journal of Int'L Affairs, Vol 4, Issue 2 (2021)

Pak-China Relations: An Analysis...

In 1984, the Chinese President, Li Xiannian, made a trip to Pakistan. In 1986, China and the United States inked a comprehensive nuclear cooperation deal during President Xiannian's government. Later, China delivered a range of nuclear products and services to Pakistan, including technical support and enrichment research of uranium, as well as nuclear power reactors. The invasion of Afghanistan by the Soviet Union in 1979 constituted a danger not just to regional stability but also to global peace and security. A joint effort between Pakistan and China was made to cope with the Afghan crisis. As part of its backing for Pakistan during the Afghan War (1979-89), China sent military supplies worth \$200 million a year to Afghan opposition organisations. Chinese assistance in the establishment of Pakistan's ballistic missile programme helped to boost Pakistan's strategic might in the South Asian area. (Khan, 2015)

\section{After Cold War}

With increasing Sino-Indian ties, Pakistan did not have any reservations in the 1990s. In Pakistan, the strengthening of ties between India and China was seen as a good development, with no suggestion that it might harm Pakistan's relations with China. Many believed that China and India's strengthening ties would limit the expanding Indian presence in Kashmir. From neutrality to support for Pakistan's viewpoint, China has already made a shift in policy. Over time, China developed a clear position on Kashmir and supported peaceful resolution of the conflict there. China's sovereignty over Tibet, Hong Kong, or Taiwan was always a priority for Pakistan in return for Pakistan's complete support in these matters. (Gulshan, 2020)

Sanctions on Pakistan were enacted in October 1990 as a result of the Pressler Amendment of 1985. 19 A total of \$564 million in planned U.S. aid for Pakistan's fiscal year of 1991 was cancelled and the U.S. military support was fully curtailed during the 1990s." China's ties with Pakistan were stronger during that time. The post-Cold War period saw a high-level exchange of visits between Pakistan and China. In 1989, Benazir Bhutto travelled to China, and in the following year, China's Prime Minister Li Peng visited Pakistan in return. In 1991, China's President, Yang Shangkun, made a trip to Pakistan to further strengthen bilateral ties between the countries. Jiang Zemin visited Pakistan in 1996 and the two countries resolved to enhance bilateral relations. Chashma nuclear power station, a 300 MWe facility in Kundia Town in the district of Mianwali in Punjab province, was built with assistance from China in 1999. When Zhu Rongji, China's Prime Minister, visited Pakistan in 2001, President Pervez Musharraf also travelled to China. Expanded military and space technology collaboration between the two countries strengthened bilateral ties. Pakistan's most trustworthy defence equipment supplier is now China. As part of their post-Cold War defence cooperation, China and 


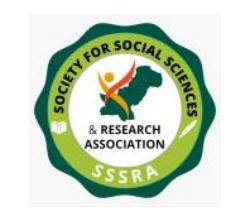

Pak-China Relations: An Analysis...

Pakistan signed a Memorandum of Understanding (MoU) in June 1990. Ten years of procurement, $R \& D$ knowledge transfer, and co-production were included in the Memorandum of Understanding (MoU). After the United States enacted the Pressler Amendment, this time period was extended. The MBT-2000 Al-Khalid was jointly designed, developed, and manufactured by the United States and Saudi Arabia in January 1990. The T902M is a revamped version of the original design. In August of 1991, the first Chinese-made prototypes were put to the test in the field. Since the Heavy Mechanical Complex at Taxila was built in 1992, much of the development work has been devoted to making it more suitable for Pakistan's topography and high temperatures. There was a programme known as "Thunder" that began in 1999 to develop JF-17 jet fighters. The major goal of this initiative was to reduce dependency on Western jetfighter manufacturers. (Lamont \& Bokhari, 2011)

\section{Relations Since 9/11 Attack}

After the US participation in Afghanistan, the strategic dynamics of the Southwest Asian area were changed by the 9/11 events. Additionally, there has been a rise in strategic interdependence between the two countries throughout this time. China, like Russia and the United States, forged strategic alliances with emerging nations and restructured its bilateral and multilateral relationships. There is no doubt that Pakistan's connection with China has played a pivotal role in this predicament. As a result, South Asia's geopolitical affairs were thrown into turmoil in the 1990s, it featured the nuclearization of South Asia in 1998, the Kargil War, the war on terrorism, the US invasion of Afghanistan, and the military standoffs between India and Pakistan in 2001 and 2002, among other events The Kargil conflict and military standoffs between India and Pakistan were significant events in the history of the world since both countries had nuclear weapons at the time. The U.S. and China played a positive role in reducing these tensions. (Ahmad, 2013)

Since the terrorist attacks on September 11, 2001, there's been an enormous shift in the way people think about security. An ever-expanding phenomenon that includes both conventional and nontraditional threats. As a result of the worldwide war on terrorism, expanding U.S. strategic cooperation with India, China's economic linkages, and regional shifts in the Asia-Pacific area, Pakistan-China ties have been seriously harmed. One of China's most important roles in the region's peace and security is due to its strong business relationships with South Asian countries. The China-Pakistan Economic Corridor, for example, will link Xingjian with Pakistan's Gwadar deep seaport. The Gwadar Port, a huge network of railway lines and roads, thermal and hydropower, electronics and mining, as well as nuclear energy, have all been sponsored by China. The infrastructure development of Sri Lanka has been heavily influenced by China. 


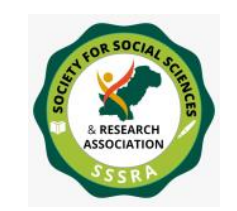

Pak. Journal of Int'L Affairs, Vol 4, Issue 2 (2021)

Pak-China Relations: An Analysis...

Megaprojects in Bangladesh and Nepal are being constructed by its enterprises. The predominant strategic alignments in the region were also reevaluated in light of changes in geopolitical circumstances. A non-Nato ally designation was granted to Pakistan because of its role as a frontline state in the U.S.-led fight on terror. An alliance between America and India was formed following the Mumbai terrorist attacks of 2008, and the Indo-Pakistani relationship suffered a major setback. South Asia's spatial paradigm was shifted by the development of such occurrences Drone attacks by the United States and strategic collaboration with India swallowed Pakistan's sovereignty and territorial integrity in the post-9/11 regional dynamics. Both nations supported one another in this dangerous crisis, but they also advanced their bilateral strategic collaboration in the economic and military fields. There are, however, a few sectors, such as counterterrorism, Afghanistan, and energy security, that have given its strategic partnership a fresh perspective. (Rehman, 2019)

Researchers, including Shamshad Ahmad and Liu Zongyi from the Shanghai Institutes for International Studies as well as Shahzad Akhtar from a strategic studies institute in Pakistan, have suggested that Pakistan and China's strategic collaboration began as a result of their shared interest in India. A number of new factors have, however, contributed to the seeming shift in Pakistan-China strategic ties after 9/11, particularly from a post-9/11 perspective. China Institutes of Contemporary International Relations (CICIR) Senior Researcher Hu Shisheng believes that Pakistan and China's strategic cooperation has undergone considerable transformations, mutual checking and power balance and moving away from the Cold War mentality of confrontation and toward postCold War thinking that emphasises common development, shared destiny, and an appreciation of responsibilities. Pakistan and China's strategic cooperation Relationships between Pakistan and China have remained friendly since the September 11 attacks and have developed into "strategic partners" and "good brothers," respectively. (Ahmad, 2013) Since the United States' participation in Afghanistan and the rise of Indo-US strategic cooperation, Pakistan and China's strategic interdependence has grown dramatically. High-level visits were exchanged, and the two countries signed a "Treaty of Friendship, Cooperation, and Good Neighbourly Relations" on April 5, 2005, in which they agreed to refrain from joining "any alliance or bloc that infringes upon the sovereignty, security, or territorial integrity of either nation," as well as stating that they would not conclude treaties on this subject in the future. Beginning in 2001, both countries worked together on the building of Gwadar port, which was completed in July 2013 after signing a Memorandum of Understanding on the CPEC. On April 20, 2015, the nations inked an agreement to begin a development project in Pakistan valued at US\$ 46 billion, which would begin immediately. (Watson \& Han, 2011) When NATO soldiers launched an offensive on Pakistani border areas in November 2011, killing 26 Pakistani 


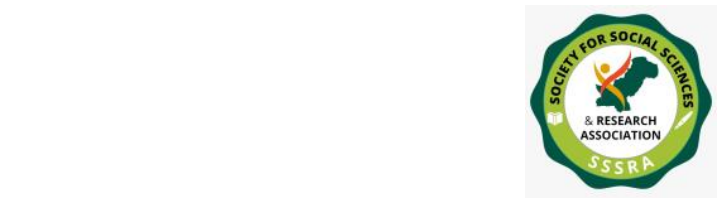

Pak. Journal of Int'L Affairs, Vol 4, Issue 2 (2021)

Pak-China Relations: An Analysis...

army men, China responded violently and retaliated. In the words of a Chinese government official, "any danger to Pakistan will be treated as a direct threat against China." 35 COPHC was awarded the administration of Pakistan's Gwadar port in 2013. This was the first time that COPHC has been granted this responsibility. During his visit to Pakistan, China's Prime Minister Li Keqiang inked many agreements with the country. Significant progress was made this year when CPEC, which connects Gwadar Port in Pakistan and Xinjiang, China, was given the go-ahead. On December 31, 2013, China said it will build a nuclear power station in Karachi that could generate energy with a capacity of 2200 megawatts. One of the two reactors would have a total capacity of 1,100 megawatts, and the Chinese National Nuclear Cooperation (CNNC) has agreed to lend the project at least US\$6.5 billion. By the end of 2019, it would be completed. " There would be more power in the two reactors than all of Pakistan's already operational nukes." More than US\$31 billion will be invested in the expansion of the energy industry, infrastructure, and building of Gwadar port by China this year. Pakistan and India have also agreed on the construction of a metro rail service in Lahore, which is expected to commence operating in 2019. At the Boao Forum for Asia in April 2014, Pakistani Prime Minister Muhammad Nawaz Sharif travelled to China (BFA). (Sattar, 2015)

On the occasion, he said Pakistan was prepared to increase its strategic cooperation with China, which has been the "cornerstone" of Pakistan's diplomacy. 38 To attend the AsiaPacific Economic Cooperation summit, Nawaz Sharif returned to China in November of that year (APEC). Aside from the meeting with China's leader, he made it clear to Xi Jinping that Pakistan will continue to fight the East Turkestan Islamic Movement (ETIM) terrorists. Pakistan and China would "jointly preserve regional peace and stability" in Afghanistan, he added. CPEC-related energy and infrastructure projects were announced in November 2014 by the Chinese government. Pakistan's economy will be boosted by large-scale initiatives in a variety of sectors, including energy, infrastructure, and connectivity, which would alleviate the country's power crisis. It takes 9500 miles to go from the Middle East to Shanghai by sea, but the 2500-mile route via Pakistan's Gwadar port is the quickest way to get to Xinjiang. The Indian Ocean and the Malacca Straits are China's primary sources of oil imports. Beijing's energy supply might be stifled by a conflict or terrorist assault, notably in the Malacca Strait if current oil import routes are stopped. A territorial dispute in the South China Sea exacerbates worries about China's energy security, as it includes Malaysia, Japan, Taiwan, the Philippines, Brunei and Vietnam. (Ahmad, 2013)

\section{Changing Alliances}




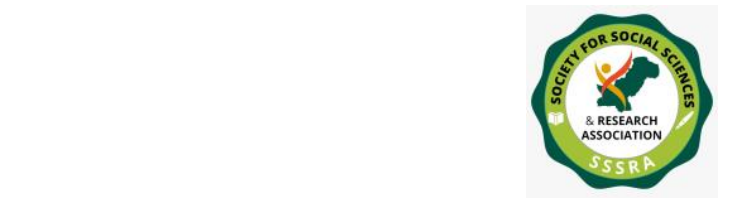

Pak-China Relations: An Analysis...

In the wake of regional alliances, the modern military equilibrium between Pakistan and India has also changed. The post-9/11 era provided a platform for military collaboration between Pakistan and the United States. However, the tight relations between the United States and India have also had an impact on the overall relations between the two nations. The US has become more concerned about India's security because of its potential to become a stronger regional role and its cooperative nature. As a result of the tight relationship between the United States and India, the general ties between the two nations have also been altered. As a result, the transfer of technology from the United States to India might have a significant impact on the security of Pakistan. Arunachal Pradesh and the Aksai Chin sections of their shared border are still a source of friction between India and China, although bilateral ties between the two countries are on the rise and they are engaged in constructive talks to address the border problem. Both countries' bilateral commerce has also seen a significant uptick in recent years. A total of US\$84.44 billion in commerce was conducted between China and India in 2017. A total of US\$1.7 billion was invested in India through Chinese FDI. On June 28, 2005, 'The New Framework for the US India Defense Relationship' was signed as a significant milestone in US-India ties. The military pact, which had been in place for ten years, was renewed in June 2015 for another ten years after it expired. In light of this, it is evident that the United States has shifted its focus to India. With their collaboration on missile defence, Pakistan's nuclear constraint has been undermined. The strengthening of India's ties with Japan and the consolidation of Indian relations with the United States is influencing the strategic stability in South Asia as well as in East Asia. (Javaid \& Fatima, 2012)

\section{Infrastructure, Trade and Financial Relations}

China and Pakistan have also developed increasingly strong business ties in recent years. Despite the fact that the United States is Pakistan's largest export market, China is the country's largest bilateral trade partner overall, as well as its greatest source of new foreign direct investment inflows and a key source of bilateral credit. Approximately $\$ 12.1$ billion worth of goods and services were traded between the two nations in 2018 2019 , representing an increase of more than $50 \%$ over the previous five years. Chinese exports to Pakistan, on the other hand, account for more than 87 per cent of the overall trade volume, and Pakistani exports to China have had slow growth for much of the last decade as well. Despite the fact that the trade connection is not widely discussed in Pakistan's domestic discourse, tensions exist between the two countries. Pakistani industries and enterprises have raised worries about Chinese goods flooding the domestic market and displacing local firms. Chinese President Xi Jinping's Belt and Road Initiative, which includes the China-Pakistan Economic Corridor, was the centrepiece 


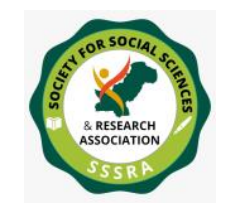

Pak. Journal of Int'L Affairs, Vol 4, Issue 2 (2021)

Pak-China Relations: An Analysis...

project, and its development has resulted in a significant increase in Sino-Pakistani economic cooperation. Beyond the economic component of the collaboration, the commencement of this initiative coincided with the development of high-level strategic interaction as well as a prioritising of the bilateral relationship with Pakistan by Chinese policymakers. Although actual investments under CPEC have yet to reach the levels initially announced - some estimates put the figure as high as $\$ 60$ to $\$ 80$ billion over the course of a decade-CPEC has provided Pakistan with a much-needed infusion of infrastructure financing from China at a time when many other countries' investment levels had fallen to extremely low levels. It has also helped to increase capacity in Pakistan's strained energy sector, which has been particularly beneficial. (Yousafzai, 2018)

The Chinese government and commercial banks have acted as a lender of last resort for Pakistan in addition to funding CPEC projects, virtually all of which are performed on commercial terms. To avoid an impending balance-of-payments crisis in Pakistan in 2018 and 2019, China and a few other important allies, such as Saudi Arabia, provided Pakistan with a limited amount of short-term credit assistance, most recently in 2018 and 2019. A total of 24 per cent of Pakistan's overall public debt burden is owed to China, with CPEC-related projects accounting for 6.8 per cent of that total, according to Pakistani officials in November 2019. Officials in Pakistan and China have frequently defended their CPEC-related obligations, but they have also restricted access to information concerning project finance that would have allowed for a more comprehensive study of the conditions of these agreements. There are major budgetary limits in Islamabad. Even before the COVID-19 outbreak, Pakistan's domestic income collection had already begun to decline, increasing concerns about the country's total debt burden. Only a quarter of the officially specified CPEC projects were finished by April 2020, although execution has stalled since Pakistan's 2018 legislative elections when the country's administration was replaced. While China's foreign direct investment in Pakistan fell to its lowest level for five years, some new government officials advocated for renegotiating CPEC contracts or pursuing investigations into projects that had been started by their political opponents during the PTI's first year in power. (Shisheng, 2014)

To date, the PTI government's promises to refocus CPEC on social development investments through the creation of special economic zones in Pakistan to boost manufacturing and industrial production are dead on arrival It is difficult for Pakistan to give more funding for these initiatives because the country's rigid regulatory frameworks. A key concern for US and Indian military strategists is the delayed progress of the Gwadar port complex in Balochistan, which they see as a possible dual-use facility capable of assisting Chinese maritime force projection. Chinese soldiers have been put in 


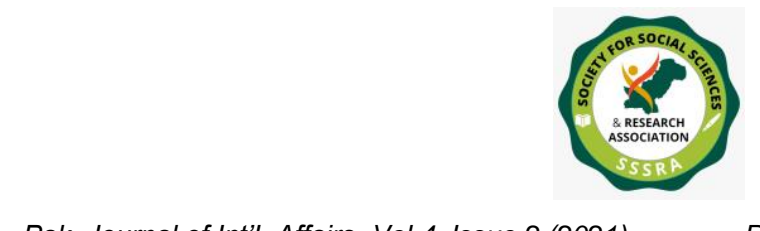

Pak-China Relations: An Analysis...

jeopardy by repeated attacks by local rebels. There is a corresponding lack of interest from potential investors in the port. Pakistan's development of its Mainline One railway route has thus far been the only large-scale project that has been added to the CPEC portfolio since its debut in 2015, prior to the PTI government taking office. It is unknown if China will agree to PTI government officials' suggestions to adjust loan repayment schedules or guarantee rates of return for CPEC-supported energy projects, although it has been reported that such actions have been floated in the past. Some Chinese officials and experts have indicated a degree of buyer's remorse regarding the CPEC project in conversations with Senior Study Group members. With its high profile in the bilateral relationship and as a cornerstone of the larger BRI programme, even in the face of setbacks, CPEC still puts a premium on both parties being able to portray it as long-term success. In any case, with the commencement of the COVID-19 epidemic, large new Chinese investments in Pakistan or the resurrection of CPEC may now be put on wait indefinitely, and concerns about debt may continue to escalate. Due to the epidemic, Chinese General Secretary Xi's next Pakistan visit has been postponed until September 2020 and has not yet been scheduled as of this writing. CPEC might benefit from fresh loans or more projects if Xi's visit is rescheduled. (Panda, 2014)

\section{Strategic Cooperation}

Pakistan is deeply concerned about the discriminatory actions of the United States towards it. During his time in office, US President Barack Obama made two trips to India, further strengthening commercial relations between the two countries. As a result of these agreements, the United States and India have promised to work together more closely on matters of defence, economics, and civilian nuclear energy (UNSC). In order to restrict China's influence in South and Southeast Asia, the United States is supporting India to take the lead in the Asia-Pacific region through the development of a strategic alliance. Using this presumption will delegitimize Pakistan's role in promoting regional stability. US-Indian defence and nuclear cooperation have prompted substantial concern in Pakistan, particularly the Indo-US nuclear accord. Pakistan, unlike India, has made considerable sacrifices in the battle against terrorism and extremism. Yet, from 2012 to 2014 , the United States gave more weaponry to India than Russia did, totalling US $\$ 5.4$ billion in arms sales to India during that time period. It was finalised on August 29, 2016, allowing both countries "the use of each other's land, air and naval bases for maintenance and replenishment," according to the Indian government. (Zafar, 2019)

BRI has implications for India's national security interests in the context of the CPEC, which India has successfully persuaded the US and Japan to share. As China's leadership has warned, if India continues to expand its strategic partnership with Japan, it would 


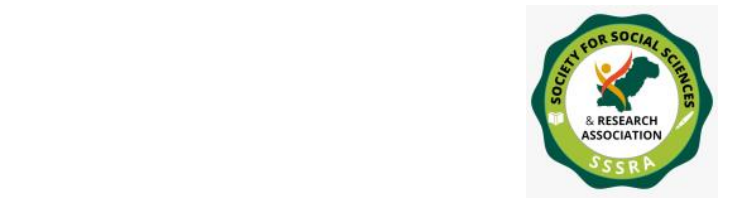

Pak-China Relations: An Analysis...

suffer considerably. Although the regional and global backdrop has changed significantly, Pakistan and China remain dedicated to ensuring the country's sovereignty and integrity. As far as the Kashmir dispute is concerned, China accepts Pakistan's position. On September 20, 2016, Chinese Prime Minister Li Keqiang reiterated China's support for the Kashmir issue. According to him, "Islamabad's attitude on the Kashmir problem is very important to Beijing." Furthermore, he said, "China stands with Pakistan and will continue to raise its voice in its support at every platform." In another step, China prevented India from designating Jaish-e-Mohammed (JeM) head Maulana Masood Azhar as a proscribed organisation at the UN on two separate occasions, in April and December of 2016. On February 7, 2017, China vehemently rejected the United States' attempt to designate Masood Azhar as a terrorist. The United States, the United Kingdom, and France had all sponsored a resolution before the UN Sanctions Committee 1267 opposing the US action. On the CPEC, China and Pakistan have rebuffed US objections. The US Defense Secretary, James Mattis, was quoted in the media as saying that the CPEC passes through contested areas as he was briefing the Senate Armed Services Committee. India is concerned that the $\$ 56$ billion projects will pass through Gilgit-Baltistan, which is part of the disputed Jammu and Kashmir region (the erstwhile Northern Areas). A joint statement by Pakistan and China has rebuffed US criticism of the CPEC, claiming that it is a regional and global economic cooperation effort. (Jones, 2020)

\section{Conclusion}

Thus, in South Asia, India created strong ties with the United States, Australia, and Japan, which in turn led to Pakistan's building of ties with China. Chinese-Pakistani events after September 11, 2001, have increased their strategic interdependence in the framework of the War on Terrorism, stability in Afghanistan, the China-Pakistan Economic Corridor in regional connectivity, and peace and stability throughout South Asia as a whole. After 9/11, India is still a major factor in Pakistan and China's strategic calculations, but there are many other elements that will continue to enhance their strategic interdependence in the future. A few examples of these factors are cooperation in the fight against extremism and terrorism as well as a convergent interest in regional connectivity. 


\section{References}

Afridi, M.K and Khan, A.Z. (2015) "Pak-China Boundary Agreement: Factors and Indian Reactions," International Journal of Social Science Studies 4, no.2, http://ijsss.redfame.com

Ahmad, S. (2013) “Post-9/11 Foreign Policy of Pakistan,” Criterion Quarterly 1.

Bhatti, M.A. (2008) “China’s Peaceful Rise and South Asia,” IPRI Paper13

Curtis, L. (2009) “China’s Military and Security Relationship with Pakistan,” Heritage Foundation, https://www.heritage.org/testimony/chinas-military-and-securityrelationship-pakistan

Fani, M.I. (2009) “The Indo-US Strategic Partnership in Post 9/11: Implication for Pakistan," Pakistan Vision 10, no. 2.

Gulshan, K. (2020) “Improvement in China-India Relations: Impact on Pakistan,” IPRI Review, http://www.ipripak.org/improvement-in-china-india-relations-impact-onpakistan/.

Javaid, U and Fatima, Q. (2012) "US Foreign Policy Parameters towards Pakistan and

India (2001-2008),”Journal of Political Studies 19, no. 2 (2012), 21:40.

Jones, R.W. (2020) "Nuclear Stability and Escalation Control in South Asia: Structural Factors," Stimson, http:// www.stimson.org/ images/ uploads/ researchpdfs/ ESCCONTROLCHAPTER2.pdf.

Khan, J. (2015) "US-Pakistan Relations in the Post-Cold War Era: Implications for World Peace,” MAGNT Research Report 3, no.4, 211-225.

Lamont, J. and Bokhari, F. (2011) "China and Pakistan: An Alliance is Built," Financial Times, June 30, 2011.

Pakistan-China Institute. (2018) "The Karakoram Highway: A Friendship Channel," http://www.pakistan-china.com/mn-

backgroundersdetail.php?id=MQ==\&pageid=news 
Panda, A. (2014) "Can Pakistan and China Successfully Cooperate on Counterterrorism?," Diplomat, https://thediplomat.com/2014/05/can-pakistanand-china-successfully-cooperate-on-counterterrorism/

Rahman, F (2019) "Traditional and Emerging Areas of Strategic Cooperation between Pakistan and China," http://pcc.org.pk/downloads/traditional-and-emerging-areasstrategic-cooperation.pdf

Sattar, H. (2015) “China and Pakistan's All-Weather Friendship,” Diplomat, March 12, 2015.

Shisheng, H. (2014) Senior Researcher, China Institutes of Contemporary International Relations (CICIR), Interview conducted by the author, Beijing, July 28, 2014.

Watson P.J. and Han, Y. (2011) "Chinese Government Official: US Threat to Pakistan is Threat to China," Infowars.

Yousafzai, R. (2018) Resident Editor, News, Peshawar, Personal Interview by the author, April 28, 2018, Islamabad.

Zafar, H. (2019) “The Corridor of Hope,” Daily Times. 